\title{
Are Sri Lankan Reefs Losing the Resilience? An Example from Coral Reefs in Sallitive Island
}

\author{
Ranatunga R.R.M.K.P. ${ }^{*}$, Weerasinghe R. ${ }^{1}$, Prasad J.A.C. ${ }^{2}$ and Pethiyagoda P.D.R.S. ${ }^{1}$ \\ ${ }^{1}$ Department of Zoology, University of Sri Jayewardenepura, Sri Lanka \\ ${ }^{2}$ National Aquatic Resources Research and Development Agency, Sri Lanka \\ *kamal.ranatunga@gmail.com
}

\begin{abstract}
Coral reefs are known to undergo phase shift in to macro-algae and reefs have lost the capacity to remain in or return to a coral-dominated state. This shift will not only affect corals, but the others heavily depend on heterogeneous habitat afforded by corals. Sallitivu in Panichchankerni, Eastern province, is a small island $\left(41328 \mathrm{~m}^{2}\right)$. The Island is surrounded by a ring of coral reef with an elevated breaking reef crest, seaward slope and centred shallow lagoon $(<1.2 \mathrm{~m}$ at high tide). The shore is entirely a thick layer of washed coral rubbles. The archived aerial photographs confirmed these coral rubbles present only after 2004 tsunami.

Underwater visual census were carried out within the reef lagoon and three sites in reef slope using $30 \mathrm{~m}$ long belt transect. In addition to diversity of corals and algae, percentages of live, dead and bleached coral cover were recorded. The reef lagoon is shallow $(10-60 \mathrm{~cm})$ and much of the reef crest is exposed at low tide. Within the reef lagoon, the live coral cover was $<5 \%$. Around $15 \%$ was observed recently bleached, $12 \%$ were overgrown by algae; Padina sp, Halimeda sp, Sargassum sp, Caulerpa recemosa and Dictyota sp, and the rest was dead corals smothered by sediments. The seaward slope with high wave action was mostly smothered dead corals with live corals $<3 \%$. Coral colonies were represented by Acroporidae (branching and table corals)Acropora cytherea, A. divaricata, A. formosa, A. gemmifera, A. grandis, A. hemprichii, A. hyacinthus, A. latistella, Acropora sp., A. nobilis, and A. robusta; (Foliaceous)-Montipora aequituberculata and M. hispida; Faviidae (sub massive and encrusting)-Favites halicora, Favites spinosa, Leptastrea purpurea and Platygyra daedalea; Pocilloporidae (Lace/cauliflower) Pocillopora damicornis; Poritidae (Massive/submassive)-Porites evermanni, P. paliformis, and P. rus. Live corals observed were immature. Southern end of the reef slope had emerging corals among unstable coral rubbles. It is assumed that the degradation was started post-tsunami and continued due to natural stresses. The recovery of corals may hindered by macro-algal growth and resulting accumulation of sediments, smothering due to less wave action within reef lagoon and resulting recruitment and settlement failure. Recent bleaching would be due to exposure to direct sunlight during the change of tides and low sea level. Increasing oxygen level due to algal blooms would also prone for bleaching. Avoiding such undesirable phase shifts from coral dominance to algae and reverse them when occur, requires an urgent reform of scientific approaches to understand the processes causing the degradation. A better understanding on why some reefs rapidly degrade and others do not is critical. Most reef conservation efforts are directed toward reserve implementation, but new approaches are needed to sustain ecosystem function since demarcation of a marine reserve alone would not benefit in improving reef resilience.
\end{abstract}

Keywords: Phase-shift, Coral reefs, Macro-algae, Bleaching, Sallitive Island

Proceedings of the International Forestry and Environment Symposium 2016, Department of Forestry and Environmental Science, University of Sri Jayewardenepura, Sri Lanka. 